\title{
Subject Matter Knowledge of Prospective Mathematics Teachers on Quadratic Functions Using Problem-Based Learning
}

\author{
Tina Sri Sumartini ${ }^{1 *}$ iD \\ ${ }^{1}$ Mathematics Education, Institut Pendidikan Indonesia, Jawa Barat, Indonesia \\ *Corresponding author: tinasrisumartini@institutpendidikan.ac.id
}

\begin{abstract}
Subject matter knowledge is important knowledge possessed by prospective mathematics teachers. In general, this study aims to examine the achievement of Subject Matter Knowledge (SMK) of mathematics teacher candidate students who study with the Problem Based Learning (PBL) model. This study used a mixed-method. The research design used was explanatory sequential design. The population consisted of undergraduate students of the Mathematics Education Study Program. The sample used was 80 students of prospective mathematics teachers consisting of 40 students in the PBL class and 40 students in the CL-class. The results obtained were: the achievement of the vocational students of mathematics teacher candidates who studied with PBL was better than those of prospective mathematics teacher students who studied with conventional learning. In addition, from the five indicators, four indicators experienced a high increase and one indicator experienced a moderate increase, namely the indicator of the ability to connect the concept of a quadratic function in everyday life.
\end{abstract}

Keywords: Subject Matter Knowledge, Quadratic Function, Problem Based Learning

$\begin{array}{lll}\text { History: } & \text { Publisher: Undiksha Press } \\ \text { Received } & \text { : 6 January } 2021 & \text { Licensed: This work is licensed under } \\ \text { Revised } & : 15 \text { February } 2021 & \text { a Creative Commons Attribution 3.0 License } \\ \text { Accepted } & : 20 \text { March } 2021 & \end{array}$

\section{Introduction}

An educator in the field of mathematics must have the ability and skills to develop creative and innovative abilities in learning, understand the development of child psychology, develop communication skills in teaching, have a broad knowledge of mathematics, and be able to develop knowledge of mathematics education (Ak \& Özkarde, 2007; Burhanzade \& Aygör, 2014). The teacher must explain mathematical concepts in the form of different representations and provide clear examples and be able to relate them in everyday life. Haciomeroglu (2006) states that a teacher must learn procedural (the formal language of mathematics and algorithms to solve math problems), conceptual (recognize and produce relationships between units of knowledge), and understand and use inductive and deductive reasoning in mathematics. In addition, Grossman, Wilson, \& Shulman (1898) states that subject matter knowledge involves four dimensions, namely content knowledge, substantive knowledge, syntactic knowledge, and beliefs about the subject matter.

Subject Matter Knowledge (SMK) is the teacher's knowledge of the concept of a subject or the origin of the subject matter which can be accepted or rejected (Deborah Loewenberg Ball, Thames, \& Phelps, 2008). SMK consists of: Common Content Knowledge (CCK), Horizon Content Knowledge (HCK), and Specialized Content Knowledge (SCK). 
These three knowledge are described in the characteristics presented in the following Table 1 (Deborah Loewenberg Ball et al., 2008; Shulman, 1986).

Table 1. Characteristics of Subject Matter Knowledge (SMK)

\begin{tabular}{|c|c|c|}
\hline No & $\begin{array}{c}\text { Subject Matter } \\
\text { Knowledge (SMK) }\end{array}$ & Description \\
\hline 1 & $\begin{array}{l}\text { Common Content } \\
\text { Knowledge (CCK) }\end{array}$ & $\begin{array}{l}\text { a. The knowledge that is generally used in teaching } \\
\text { mathematics material, the ability to calculate procedurally, } \\
\text { and the ability to solve problems } \\
\text { b. The ability to provide a conceptual definition of } \\
\text { mathematics and use terms and notations appropriately so } \\
\text { that it can be understood by students }\end{array}$ \\
\hline 2 & $\begin{array}{l}\text { Horizon Content } \\
\text { Knowledge (HCK) }\end{array}$ & $\begin{array}{l}\text { a. The ability to provide connections between concepts from } \\
\text { students' ideas } \\
\text { b. The ability to anticipate and make connections between } \\
\text { mathematical ideas and problems in everyday life }\end{array}$ \\
\hline 3 & $\begin{array}{l}\text { Specialized } \\
\text { Content } \\
\text { Knowledge (SCK) }\end{array}$ & $\begin{array}{l}\text { a. Teachers' skills in conveying mathematical ideas } \\
\text { appropriately } \\
\text { b. Ability to explain mathematically general mathematical } \\
\text { rules and processes } \\
\text { c. Ability to examine and understand unusual solution } \\
\text { methods } \\
\text { d. Ability to interpret different ways of operations that are not } \\
\text { normally performed by students }\end{array}$ \\
\hline
\end{tabular}

Common Content Knowledge (CCK) refers to mathematical knowledge that is not unique in teaching (Nolan, Dempsey, \& Lovatt, 2015). CCK is the teacher's knowledge of the basics of mathematics material. Every teacher has this knowledge as a basis for understanding the subject matter. Teachers need to understand the definition of mathematics and use terms or notations correctly. When implementing learning, the teacher must be able to do the assignments given to students and know when students give right and wrong answers. It is important for the teacher to have CCK because when teaching the teacher incorrectly writes notations or makes mistakes in calculations, this will result in students misunderstanding the material.

Horizon Content Knowledge (HCK) is the teacher's knowledge to connect the mathematical concepts being studied with wider mathematics in the form of material that is outside the school curriculum. This knowledge is related to the connection of mathematical material with other subjects and with everyday life. Specialized Content Knowledge (SCK) is the teacher's knowledge to deliver unique subject matter so that students can understand it accompanied by pleasant learning situations. Teaching requires more knowledge than is taught to students. Therefore, prospective mathematics teacher students must be able to solve math problems in more than one way. This will enable prospective mathematics teacher students to anticipate a variety of student answers.

Efforts to develop vocational high school mathematics teacher candidates require appropriate learning, one of which is constructivism learning. This learning has the principle that mathematical knowledge is the result of human construction. One of constructivism learning is problem-based learning. The objectives of problem-based learning according to Padmavathy (2013) are to build a broad and flexible knowledge base, develop effective 
problem-solving skills, develop lifelong learning abilities, become effective collaborators, and can motivate learning.

Table 2 . Aspects of Subject Matter Knowledge (SMK)

\begin{tabular}{|c|c|c|}
\hline Aspects SMK & Ability & Indicator \\
\hline $\begin{array}{l}\text { Common Content } \\
\text { Knowledge } \\
(\mathrm{CCK})\end{array}$ & $\begin{array}{l}\text { Understand the terms in } \\
\text { mathematical concepts }\end{array}$ & $\begin{array}{l}\text { Be able to explain operational } \\
\text { definitions of mathematical concepts }\end{array}$ \\
\hline $\begin{array}{l}\text { Horizon Content } \\
\text { Knowledge } \\
(\mathrm{HCK})\end{array}$ & $\begin{array}{l}\text { Provide a connection } \\
\text { between concepts }\end{array}$ & $\begin{array}{l}\text { 1. Able to connect between mathematical } \\
\text { concepts } \\
\text { 2. Able to connect mathematical concepts } \\
\text { with problems in everyday life }\end{array}$ \\
\hline $\begin{array}{l}\text { Specialized } \\
\text { Content } \\
\text { Knowledge } \\
\text { (SCK) }\end{array}$ & $\begin{array}{l}\text { Convey mathematical } \\
\text { ideas appropriately in } \\
\text { problem-solving }\end{array}$ & $\begin{array}{l}\text { 1. Able to provide the correct concept in } \\
\text { solving math problems } \\
\text { 2. Be able to provide different ways of } \\
\text { solving math problems }\end{array}$ \\
\hline
\end{tabular}

Problem Based Learning (PBL) models have an effect in learning mathematics to improve student understanding and the ability to use mathematical concepts in the real world (Ak \& Özkarde, 2007). In addition, problem-based learning helps students develop knowledge flexibility, the ability to provide effective solutions to problem-solving, independent work skills, effective collaboration skills, and intrinsic motivation (HmeloSilver, 2004).

Subject Matter Knowledge (SMK) teachers in mathematics learning need to be developed as a basis for solving math problems. With regard to SMK, many teachers find it difficult to connect daily life problems in learning (Lee, Capraro, \& Capraro, 2018). This is a recommendation for research to identify vocational mathematics teacher candidates through providing problems in learning. Educational programs regarding vocational high school mathematics teacher candidates need to be designed in an integrated manner by combining insights from various disciplines by giving problems (Scheiner, Montes, Godino, Carrillo, \& Pino-Fan, 2019). In PBL, student-teacher candidates will be faced with mathematics applications that will develop SMK.

A teacher who has a strong SMK will be able to prepare students more effectively for learning (Tchoshanov et al., 2017). This study aims to analyze SMK mathematics teacher candidates using PBL. SMK analysis is carried out in the field of algebra as a recommendation from the research results (Norton, 2018) which states that improving SMK in the field of algebra requires special attention and a correlation between the two is

\section{Materials and Methods}

This study used a mixed-method. The research design used in this study was an explanatory sequential design. In this design, quantitative data were collected first and then qualitative data were collected to help explain or elaborate on quantitative results (Creswell, 2015). Quantitative data were obtained from the test results of students who studied with Problem Based Learning (PBL) and Conventional Learning (CL) models. The sampling process in this study was not done randomly, according to Cohen, Manion, Lecturer, Morrison, \& Lecturer (2007) this research is called quasi-experiment. The design used in this quasi-experimental study was the pre-test post-test non-equivalent group (Cohen et al., 2007). The reason for choosing this design was because the subjects in this study had been grouped into one class from the start when they entered and were registered as students. The 
population in this study were all students of the Undergraduate Mathematics Education Study Program at one of the Teacher Training Institutions in West Java province. Sampling was done by means of purposive sampling. This is done based on the researcher's considerations related to the research needs. The sample used was 80 students of prospective mathematics teachers consisting of 40 students in the PBL class and 40 students in the CL-class. The data were collected by giving a written test on the quadratic function material based on the SMK indicators and interviews. Data analysis was carried out quantitatively using statistics and qualitative by observing the results of student answers and interviews.

\section{Results and Discussion Results}

The Data were analyzed inferentially to establish the achievement of prospective mathematics teachers who learned with PBL with CL. The inferential analysis used was the normality test and the difference between the two means. The results of the normality test of SMK attainment data can be seen in table 3.

Table 3. Normality test of Achievement Data of SMK Prospective Mathematics Teachers

\begin{tabular}{ccc}
\hline Normality Test (Saphiro-Wilk) & \multicolumn{2}{c}{ Learning } \\
\cline { 2 - 3 } & PBL & CL \\
\hline Statistic & 0.941 & 0.969 \\
df & 40 & 40 \\
Sig. & 0.036 & 0.323 \\
\hline
\end{tabular}

Based on table 3, for the PBL class the value of sig $<0.05$ was obtained, so Ho was rejected, meaning that the achievement data of the PBL class SMK came from a population that was not normally distributed. Whereas for the CL class, the value of sig.> 0.05 was obtained, so Ho was accepted, meaning that the data on the achievement of the vocational school mathematics teacher candidates for CL class came from a normally distributed population.

The next step is to test the differences in the achievement of prospective mathematics teachers in both classes using non-parametric tests. This test was used because one class was not normally distributed. The results of the Mann Whitney test, data on the achievement of prospective mathematics teachers can be seen in table 4 .

Table 4. Mann Whitney Test of Achievement of Prospective Mathematics Teachers

\begin{tabular}{ccc}
\hline Mann Whitney Test & PBL $\quad$ CL & Testing Criteria \\
\hline Mann Whitney U & 347.000 & \\
Z & -4.386 & Ho is rejected \\
Sig.(1-tailed) & 0.00 & \\
\hline
\end{tabular}

From Table 4, the value of sig. $<0.05$ is obtained, so Ho was rejected, meaning that the achievement of prospective mathematics teachers who study with PBL is better than those of prospective mathematics teacher students who study with CL

Based on the findings regarding student vocational schools, it was found that the achievement of vocational students who studied with PBL was better than students who studied with CL. This indicated that the difference in achievement and improvement of student vocational schools is influenced by the use of learning models. 
To determine the achievement of the SMK indicators in both classes, calculations were made of each indicator so that the improvement was known. The results of each indicator are presented in table 5.

Table 5. Description of Each SMK Indicator

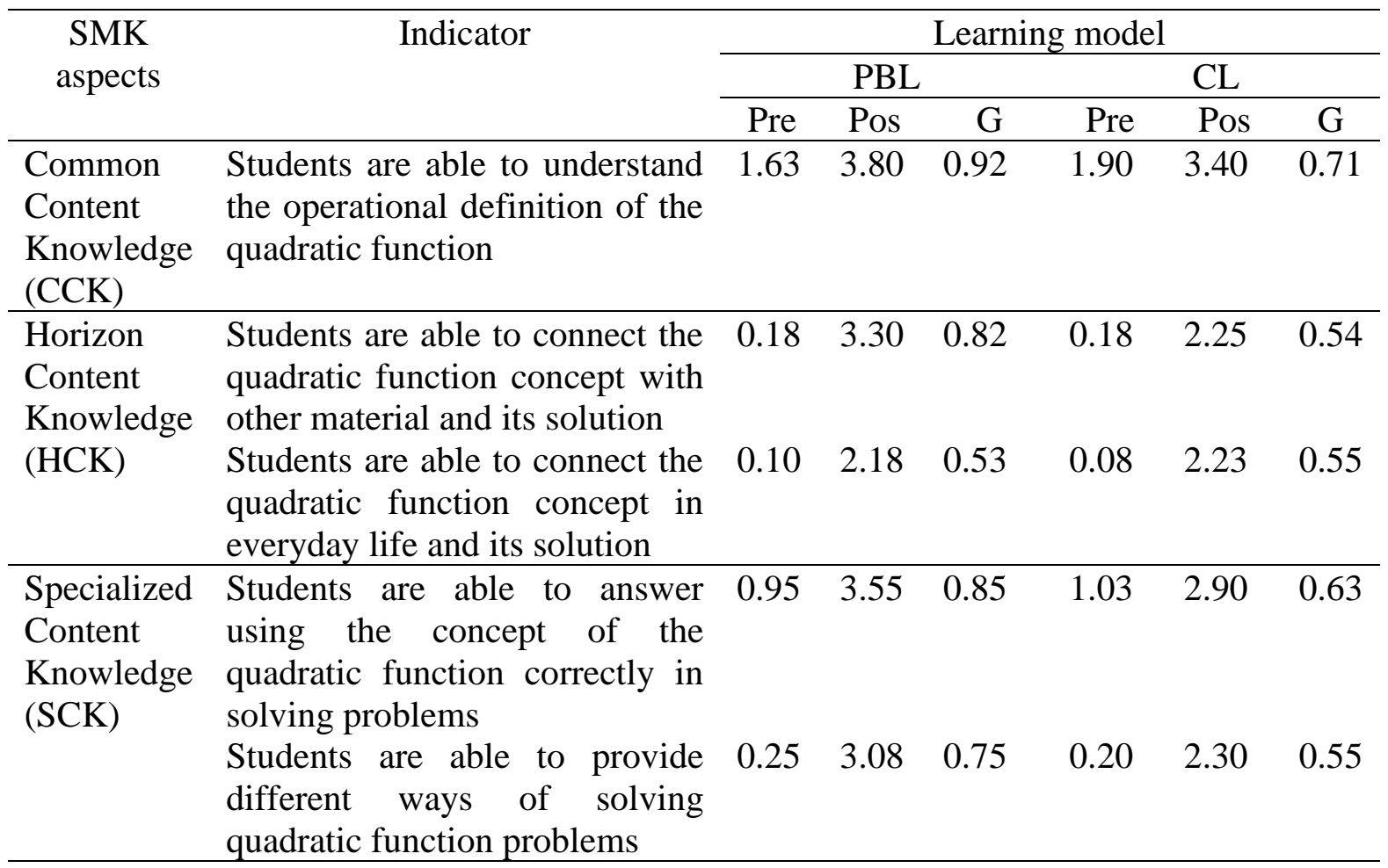

Based on Table 5, for the CCK aspect, the increase in students' ability to understand the operational definition of the quadratic function, both the PBL class and the CL class have high interpretations. For the HCK aspect, the increase in students' ability to connect the quadratic function concept with other material in the PBL class has a high interpretation but the CL class has a moderate interpretation. Meanwhile, the improvement of students' abilities in connecting the quadratic function concept with daily life, both the PBL class and the CL class had moderate interpretations. Furthermore, for the SCK aspect, the increase in students' ability to answer by using the concept of quadratic functions correctly in solving problems and the ability of students to provide different ways of solving quadratic function problems in the PBL class has a high interpretation while the CL class has a moderate interpretation.

Based on these results, the ability of students in the PBL class still has a moderate interpretation of the ability to connect the concept of quadratic functions in everyday life. This is supported by the results of interviews with students who stated that the material that was considered difficult was the application of the quadratic function.

The following showed the results of observations on student answers regarding the ability to connect the concept of quadratic functions in everyday life. Teachers can complete items related to general content knowledge but have difficulty exploring other dimensions of their knowledge for example about content applications (Pino-Fan, Assis, \& Castro, 2015).

Problem no 3

A basketball player throws the ball from a height of $170 \mathrm{~cm}$. The height of the basketball basket is 3 meters. The ball is thrown 4 meters from the position of the basket post and the starting position of the ball. It turns out that the throw has a maximum height of 4.5 
meters and is horizontally 2.5 meters from the player. If the throw forms a parabola, create a finishing procedure to determine if the ball goes into the basket. The answers to question no 3 of the three students are presented in Figure 1.

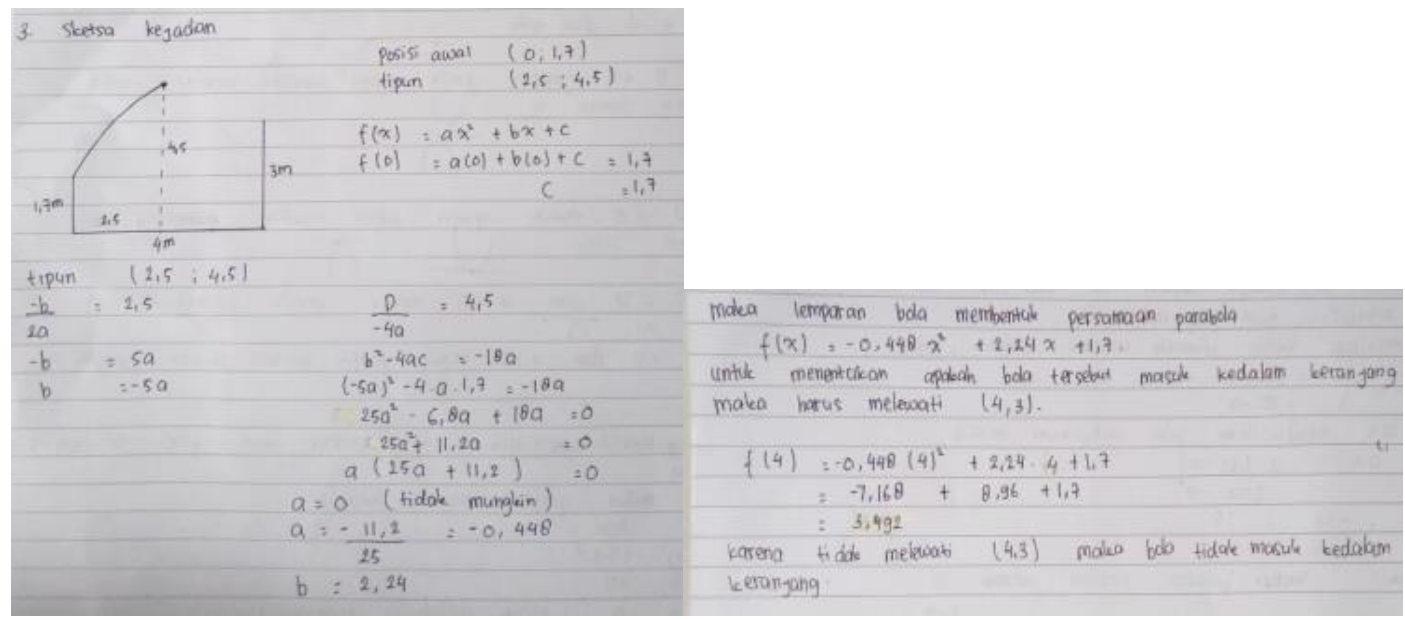

Figure 1. Answers to Question No. 3 Students 1

Student 1 provided answers and completion procedures correctly. This student began by writing down what is known and represents the problem in the form of a picture so that it could be visualized. Furthermore, this student used the formula for the vertex of the quadratic function graph to learn the correct answer. Student 2 began to answer by writing down what was known and what was asked. In writing the answer, this student immediately gave the final answer on the grounds that he substituted the vertex of the quadratic function graph into the quadratic equation formula. Wrong answers were shown by someone in solving math problems as a manifestation of their difficulty in implementing problem-solving strategies (Siswono, Kohar, Rosyidi, \& Hartono, 2017). These students felt confused in determining the right strategy for answering the problems given. The answers from student 2 can be seen in Figure 2.

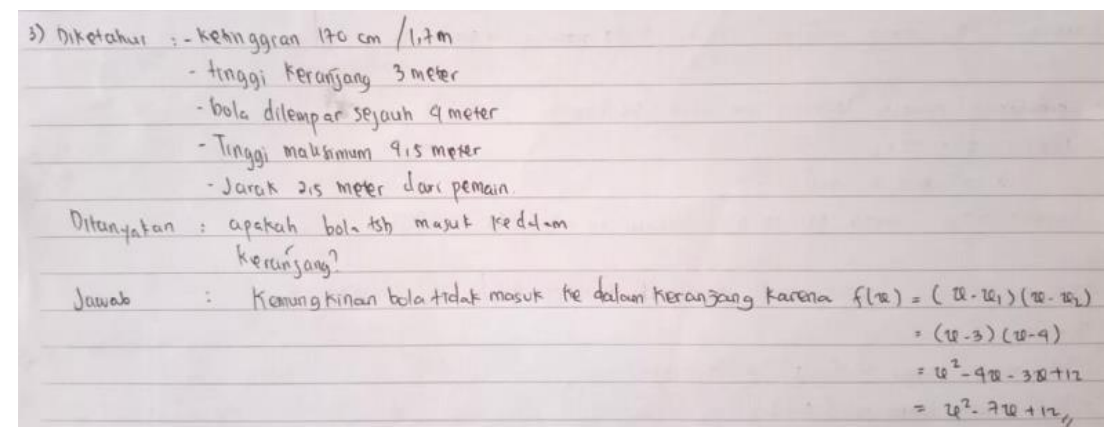

Figure 2. Answers to Question No. 3 Students 2

Student 3 gave the correct answer but without completion procedures. This was done because these students could not work on the questions so that the answers given were presumptive. The results of student 3 answers can be seen in Figure 3. 


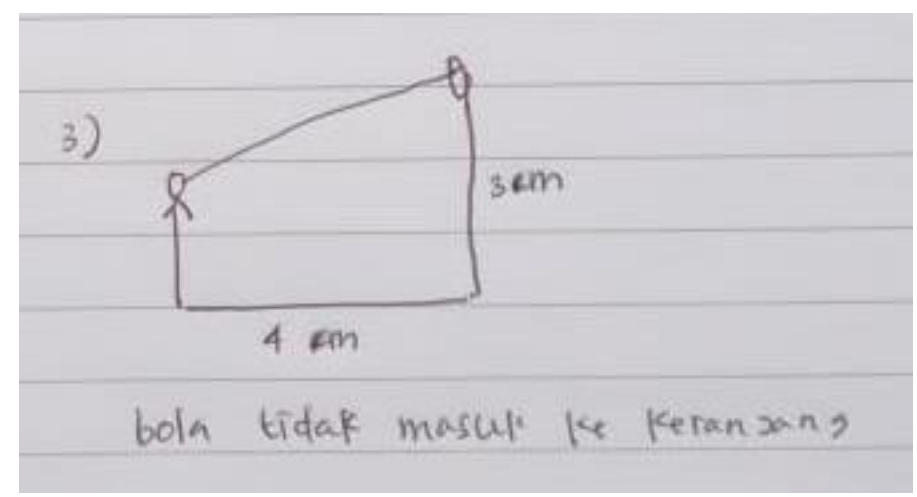

Figure 3. Answers to Question 3 Students 3

\section{Discussion}

The findings in the study showed that vocational mathematics teacher candidates had increased after learning using PBL. However, there is still something that needs to be improved in the HCK aspect, namely the ability to connect mathematics with everyday life. HCK can be said to be a broader set of mathematical ideas that become an idea (Cho \& Tee, 2018). A teacher's HCK will lead students to learn broader mathematical knowledge, so it cannot be denied that this knowledge needs to include a type of transformation that is pedagogically useful. This aspect does not appear independently but requires special specialization in the field of mathematics application. Specialization in SMK cannot be explained by what the teacher knows, but by how the teacher's knowledge emerges (Scheiner et al., 2019). HCK can be seen as a reciprocal pathway between basic mathematical knowledge and advanced mathematics.

Prospective mathematics teacher students need to master mathematics material as initial capital for teaching. The teacher as a facilitator must master mathematical material to be able to develop students' thinking skills so that their performance can increase (Ball, Thames, \& Phelps, 2016; Hill, Rowan, \& Ball, 2016). Teachers who have SMK will contribute to their pedagogical abilities. Lack of mathematical ability has an impact on the way of teaching (Brendefur, Strother, Thiede, Lane, \& Surges-Prokop, 2013).

Mathematical knowledge for teaching is professional knowledge where a teacher needs to master content to solve math problems. This will affect his ability to teach. Mathematical problem-solving knowledge for teaching is a complex network of interdependent knowledge (Chapman, 2015). This shows that the ability to solve mathematical problems in teaching will help teachers to teach meaningfully and effectively. Meaningful teaching explains the directed and contextual nature of solving math problems (Hoover, Mosvold, Ball, \& Lai, 2016).

\section{Conclusion}

Based on the results of the data analysis, it was concluded that the achievement of the vocational students of mathematics teacher candidates who studied with PBL was better than those of prospective mathematics teacher students who studied with CL. In addition, from the five indicators, four indicators experienced a high increase and one indicator experienced a moderate increase, namely the indicator of the ability to connect the concept of a quadratic function in everyday life. It is necessary to do further research on the correlation between subject matter knowledge and the pedagogical abilities of prospective mathematics teachers. 


\section{Acknowledgments}

I would like to thank the Institut Pendidikan Indonesia who has given full support so that this paper can be realized.

\section{References}

Ak, O., \& Özkarde, R. (2007). The Effects of Problem-Based Active Learning in Science Education on Students 'Academic Achievement, Attitude and Concept. Eurasia Journal of Mathematics, Science \& Technology Education, 3(1), 71-81. https://doi.org/10.12973/ejmste/75375.

Ball, D.L., Thames, M. H., \& Phelps, G. (2016). Content Knowledge for Teaching. Journal of Teacher Education, 59(5), 389-407. Retrieved from http://kprcontentlibrary.kprdsb.ca:8080/docushare/dsweb/Get/Document9589/content_knowledge_for_teaching_what_makes_it_special.pdf.

Ball, Deborah Loewenberg, Thames, M. H., \& Phelps, G. (2008). Content Knowledge for Teaching: What Makes It Special? Journal of Teacher Education, 59(5), 389-407. https://doi.org/10.1177/0022487108324554.

Brendefur, J., Strother, S., Thiede, K., Lane, C., \& Surges-Prokop, M. J. (2013). A Professional Development Program to Improve Math Skills Among Preschool Children in Head Start. Early Childhood Education Journal, 41(3), 187-195. https://doi.org/10.1007/s10643-012-0543-8.

Burhanzade, H., \& Aygör, N. (2014). Problems that the students face while solving 1 st Degree Equations with two Unknown, during their prepare to the High School Entrance Exam ( SBS ). Procedia - Social and Behavioral Sciences, 122, 477-483. https://doi.org/10.1016/j.sbspro.2014.01.1378.

Chapman, O. (2015). Mathematics Teachers' Knowledge for Teaching Problem Solving. LUMAT: International Journal on Math, Science and Technology Education, 3(1), 19-36. Retrieved from https://ohtu-calendar.it.helsinki.fi/lumat/article/view/1049.

Cho, Y.-A., \& Tee, F.-D. (2018). Complementing Mathematics Teachers' Horizon Content Knowledge with an Elementary-on-Advanced Aspect. Pedagogical Research, 3(1), 111. https://doi.org/10.20897/pr/85172.

Cohen, L., Manion, L., Lecturer, P., Morrison, K., \& Lecturer, S. (2007). Research Methods in Education.

Creswell, J. (2015). Riset Pendidikan. Yogyakarta: Pustaka Belajar.

Grossman, P. L., Wilson, S. ., \& Shulman, L. S. (1898). Teacher of Subtance:Subject Matter Knowledge for Teaching: Knowledge Base for Beginning Teacher. Profesorado, Revista de Curriculum y Formacion Del Profesorado, 9.

Haciomeroglu, G. (2006). Prospective Secondary Teachers' Subject Matter Knowledge and Pedagogical Content Knowledge of the Concept of Function. Florida State University.

Hill, H. C., Rowan, \& Ball, D. . (2016). Effect of Teacher's Mathematical Knowledge for Teaching on Student Achievement. American Educational Reseach Journal, 42(2), 371-406. https://doi.org/10.3102/00028312042002371.

Hmelo-Silver, C. E. (2004). Problem-Based Learning: What and How Do Students Learn? Educational Psychology Review, 16(3), 235-266. Retrieved from https://link.springer.com/article/10.1023/B:EDPR.0000034022.16470.f3. 
Hoover, M., Mosvold, R., Ball, D., \& Lai, Y. (2016). Making Progress on Mathematical Knowledge for Teaching. The Mathematics Enthusiast, 13(1), 52-70. Retrieved from https://scholarworks.umt.edu/tme/vol13/iss1/3/.

Lee, Y., Capraro, R. M., \& Capraro, M. M. (2018). Mathematics Teachers' Subject Matter Knowledge and Pedagogical Content Knowledge in Problem Posing. International Electronic Journal of Mathematics Education, 13(2), 75-90. https://doi.org/10.12973/iejme/2698.

Nolan, B., Dempsey, M., \& Lovatt, J. (2015). Developing Mathematical Knowledge for Teaching (MKT) for pre-service teachers: a study of students' developing thinking in relation to the tea ching of mathematics. Proceedings of the British Society for Research into Learning Mathematics, 35(1), 54-59. Retrieved from http://mural.maynoothuniversity.ie/7023/.

Padmavathy, R. D. (2013). Effectiveness of Problem Based Learning In Mathematics. International Multidisciplinary E-Journal, 2(I), 45-51.

Pino-Fan, L. R., Assis, A., \& Castro, W. F. (2015). Towards a Methodology for the Characterization of Teachers' Didactic-Mathematical Knowledge. Eurasia Journal of Mathematics, Science and Technology Education, 11(6), 1429-1456. https://doi.org/10.12973/eurasia.2015.1403a.

Scheiner, T., Montes, M. A., Godino, J. D., Carrillo, J., \& Pino-Fan, L. R. (2019). What Makes Mathematics Teacher Knowledge Specialized? Offering Alternative Views. International Journal of Science and Mathematics Education, 17(1), 153-172. https://doi.org/10.1007/s10763-017-9859-6.

Shulman, L. S. (1986). Knowledge and Teaching: Foundations of The New Reform. Harvard Educational Review, $57(1)$ $1-23$. https://doi.org/10.17763/haer.57.1.j463w79r56455411.

Siswono, T. Y. E., Kohar, A. W., Rosyidi, A. H., \& Hartono, S. (2017). Primary School Teachers' Beliefs and Knowledge About Mathematical Problem-Solving and Their Performance in a Problem-Solving Task. World Transactions on Engineering and Technology Education, 15(2), 126-131.

Tchoshanov, M., Cruz, M. D., Huereca, K., Shakirova, K., Shakirova, L., \& Ibragimova, E. N. (2017). Examination of Lower Secondary Mathematics Teachers' Content Knowledge and Its Connection to Students' Performance. International Journal of Science and Mathematics Education, 15(4), 683-702. https://doi.org/10.1007/s10763015-9703-9. 